\title{
Assessing the effect of grit and employability on organizational commitment mediating by job involvement
}

\author{
Widodo Widodo $^{\mathrm{a}^{*}}$ and Chandrawaty Chandrawaty
}

${ }^{a}$ Faculty of Education and Social Sciences of Indraprasta University, Jakarta, Indonesia

${ }^{b}$ Faculty of Teacher Training and Education, University Muhammadiyah Prof. DR. Hamka, Jakarta, Indonesia

\section{H R O N I C L E}

\section{Article history:}

Received: March 17, 2020

Received in revised format:

March 302020

Accepted: March 30, 2020

Available online:

April 6, 2020

Keywords:

Grit

Employability

Job involvement

Organizational commitment

\section{A B S T R A C T}

\begin{abstract}
The research investigated the effects of grit and employability on organizational commitment by mediating job involvement of the private higher education in Indonesia. This research used a quantitative approach with a survey method. The sample of this research is 130 lecturers selected by purposive sampling. The data were obtained by distributing questionnaires and analyzing with path analysis based on supporting correlation and descriptive statistics. The results of the research confirm that grit, employability and job involvement had significant direct effects on organizational commitment, grit and employability had significant direct effects on job involvement, and grit and employability had significant indirect effects on the organizational commitment by mediating job involvement. A fit research model was found on the effects of grit and employability on organizational commitment mediating by job involvement. This model can be discussed as a reference by researchers and practitioners in developing models of organizational commitment in the future and any context.
\end{abstract}

\section{Introduction}

Private higher education in Indonesia has not experienced significant progress as an instrument of human resources development. As an illustration, based on the ranking of the Ministry of Research, Technology and Higher Education of The Republic of Indonesia in 2019, none of the 3940 private higher education in Indonesia was ranked in the top 10. It shows that private higher education in Indonesia is not only unable to compete with public higher education, but also reflects that the private higher education in Indonesia embraces a high organizational commitment from lecturers as the main actors in the teaching, research, and community service process. Organizational commitment is the degree to which an employee identifies with the organization and wants to continue actively participating in it, willing to put forth effort on its behalf (Newstrom, 2015; Noe et al, 2015). Besides, organizational commitment reflects the attitudinal experience of commitment occurs apart from, or as a consequence of, day-to-day work activity (Beardwell \& Thompson, 2014). Organizational commitment has three indicators, namely: affective commitment, normative commitment, and continuous commitment. Affective commitment involves the employee's emotional attachment to, identification with, and involvement in the organization; continuance commitment involves commitment based on the costs that the employee associates with leaving the organization; and normative commitment involves employees' feelings of obligation to stay with the organization; it is also the right thing to do (Meyer \& Allen, 1991). Based on several research and studies in various countries, industrial, and occupational sectors, organizational commitment among others influenced grit, employability, and job involvement.

* Corresponding author.

E-mail address: widmag@gmail.com (W. Widodo) 


\section{Literature Review and Hypothesis Development}

\subsection{Grit and Organizational Commitment}

Grit is a psychological variable based on positive psychology, which prioritized the persistence as an indicator of long-term success and associated with achieving high-level goals for a very long time (Von Culin, Tsukayama, \& Duckworth, 2014; Duckworth, 2016). Grit also is demonstrated through hard work in dealing with challenges, sustaining effort and interest over the years despite being faced with failure, resilience, and difficulties in achieving it (Duckworth et al., 2007). As explained by Hochanadel and Finamore (2015) grit is one of the characteristics to help someone change the perception that the determinant of success or success is not only from intelligence. Grit shows how one can achieve long-term goals by overcoming obstacles and challenges. Grit is also one way to determine where someone can put his/her efforts to survive in facing life's challenges. According to Duckworth and Quinn (2009), grit has two indicators, namely: consistency of interests, reflects an individual's tendency to maintain commitment and maintain focus on achieving goals/tasks over a long period time; and persistence of effort, reflects an individual's tendency to pursue long-term goals with sustained efforts despite obstacles and setbacks. These indicators, in practice, can be realized for developing organizational commitment. According to Seo, Kim, and Park (2014), grit influences organizational commitment. Based on the studies and statements, the first hypothesis in this study is:

$\mathrm{H}_{1}$ : Grit has a direct effect on organizational commitment.

\subsection{Employability and Organizational Commitment}

Employability is an individual internal factor that is important for the organization, especially as a trigger for the growth of employee organizational commitment. According to Xie as a quote by Ling, Qing, and Shen (2014), employability is a new employment relationship and is the key for solving the problem of the employment relationship in the boundaryless career era. Employability also reflects how the individual perceives his or her opportunities in the labor market, one's ability to identify and realize career opportunities, and 'perceived ability to attain sustainable employment appropriate to one's qualification level (Berntson \& Marklund, 2007; Fugate, Kinicki, \& Ashforth, 2004); Rothwell, Herbert, \& Rothwell, 2008). According to Griesel and Parker (2009), employability capacities span a range of work-related skills: problem-solving and decision-making, critical thinking, communication skills (writing and speaking), proficiency in English, teamwork, interpersonal skills, research skills, information literacy, lifelong learning and ethical awareness, all-important generic graduate employability capacities. Employability can be realized if supported by five indicators that can influence it, such as specific work skills and competencies that are more general, proactive, adaptability, work feelings, a balance between organizational and personal interests (Van der Heijde \& Van der Heijden, 2006). These indicators if can be realized have potency developing organizational commitment. The results of research by Benson (2006), De Cuyper and De Witte (2011), Yousaf and Sanders (2012), and Aryani and Widodo (2020) also revealed that employability affects organizational commitment. Based on the studies and statements, the second hypothesis in this study is:

$\mathrm{H}_{2}$ : Employability has a direct effect on organizational commitment.

\subsection{Job Involvement and Organizational Commitment}

Every organization, including higher educational organization, needs a job involvement from all members of the organization, especially to build organizational commitment. Job involvement is "the level/degree in which people are known from their work, participate actively in it, and consider their achievements important for self-esteem” (Robbins \& Judge, 2013:91). Employees who have a high level of strong work involvement will tend to care about the type of work they do and actively participate and always try to understand (identify) any work given to them as well as possible following their abilities. Job involvement also refers to the positive feelings felt by employees related to the work as well as the motivation and effort they give in the job (Macey \& Schneider, 2008). In job involvement, several indicators that can be used to see an employee involved in his work, namely: active participation in work, showing work is the main thing and considers work as important to his/her self-esteem (Robbins \& Judge, 2013). If these indicators are manifested in work life, therefore they potentially increase organizational commitment, both affective, normative, and continuance commitment. Several studies also concluded that job involvement affects organizational commitment, including among others conducted by Kuruüzüm et al. (2009), Ekmekçi (2011), Ho et al. (2012), Emami (2012), Esfahani, Emami, and Tajnesaei (2013), Zopiatis, Constanti, and Theocharous (2014), Singh and Gupta (2015), and Abdallah et al. (2017). Based on the studies and statements, the third hypothesis in this study is:

$\mathrm{H}_{3}$ : Job involvement has a direct effect on organizational commitment.

\subsection{Grit and Job Involvement}

Job involvement in addition influences organizational commitment but in other conditions also it is influenced by the grit. The indicators of grit which is reflected the consistency of interests - an individual's tendency to maintain commitment and 
maintain focus on achieving goals/tasks over a long period time, and persistence of effort - an individual's tendency to pursue long-term goals with sustained efforts despite obstacles and setbacks (Duckworth \& Quinn, 2009) if in good conditions can be realized for stimulating active participation in work, showing work is the main thing and considers work as important to his self-esteem (Robbins \& Judge, 2013). The results of research carried out by Jeong et al. (2019) and Arifin et al. (2019) show that grit affects job involvement. Based on the studies and statements, the fourth hypothesis in this study is:

\section{$\mathrm{H}_{4}$ : Grit has a direct effect on job involvement.}

\subsection{Employability and Job Involvement}

Employability also influenced job involvement. While indicators of employability such as specific work skills and competencies which are more general, proactive, adaptability, work feelings, a balance between organizational and personal interests (Van der Heijde \& Van der Heijden, 2006) in good condition encourage for a participation in work, showing work as the main thing and considers work as important to self-esteem (Robbins \& Judge, 2013). However, studies on the relationship between grit and job involvement are very limited. Based on literature searches, only research by Andrew and Russlell (2012) shows an indication that employability is related to job involvement. Their results revealed the management of employability skills development highlighted a wealth of good practice within the university.

Strategies and policies to enhance employability compare favorably with benchmark institutions. They are brought to life in practice through consultancy projects, live client briefs, guest speaker programs, short and extended work placements, enterprise weekends, games, simulations, group work presentations, case studies, debates, and mock interviews. The research results of Andrews and Russell (2012) show that management of employability skills development is proven to bring practical changes that have implications for increased work engagement, especially consultancy projects, live client briefs, guest speaker programs, short and extended work placements, enterprise weekends, games, simulations, group work presentations, case studies, debates, and mock interviews. Based on the studies and statements, the fifth hypothesis in this study is:

$\mathrm{H}_{5}$ : Employability has a direct effect on job involvement.

\section{Research Methods}

This research uses a quantitative approach to the survey method. The sample of research are 130 permanent lecturers of private higher education in Indonesia spread across three provinces (Jakarta, Banten, and West Java) determined by purposive sampling based on certain characteristics (Widodo, 2019). The number of samples is good when the size is five to ten times the number of indicators (observations) of all research variables (Hair et al., 2010). The number of indicators (observations) of the four latent variables in this study is 13 , so if multiplied by ten $=130$. The details of indicators for all variables are: two indicators of grit variables, namely consistency of interest (CI), and persistence of effort (PE) (Duckworth \& Quinn, 2009), five indicators of employability variables, namely: specific job skills and competencies that are more general (SJSC), proactive (Pro), adaptability (Ada), work feelings (WF), a balance between organizational and personal interests (BBOP) (Van der Heijde \& Van der Heijden, 2006), three indicators of job involvement variables, namely: active participation in work (APW), show work is the main thing (SWMT), and consider work as something important for self-esteem (CWIS) (Robbins \& Judge, 2013), and three indicators of organizational commitment variables, namely: affective (Aff), normative (Nor), and continuous (Cons) (Meyer \& Allen, 1991).

The data was collected by a questionnaire in the form of a Likert scale model with five alternative answers: strongly disagree, disagree, neutral, agree, and strongly agree. The questionnaire was made by researchers themselves based on the theoretical dimensions of the experts. The grit questionnaire consists of 8 items with an alpha coefficient $=.832$, employability consists of 10 items with an alpha coefficient $=.892$, job involvement consists of 10 items with an alpha coefficient $=.882$, and organizational commitment consists of 10 items with alpha coefficients $=.872$. Data analysis using the path analysis and to test the significance of the path coefficient uses a t-test supported by correlational and descriptive statistics.

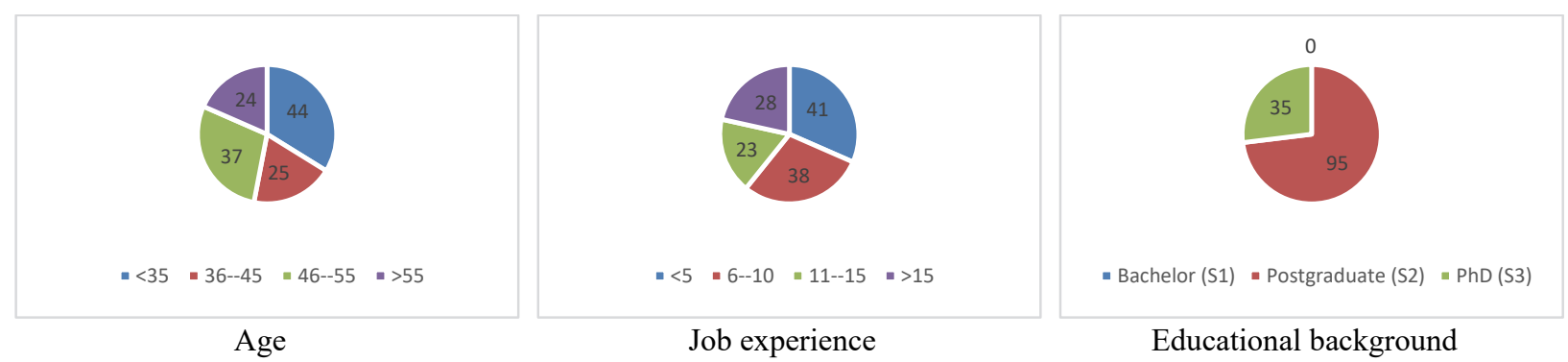

Fig. 1. Personal characteristics of the participants 
In our survey, $70 \%$ of the participants were male and $30 \%$ of them were female. In addition, $87 \%$ of them were married. Fig. 1 shows other personal characteristics of the participants. In our $\mathrm{s}$

\section{Research Result}

The results of the descriptive statistical analysis for the four research variables are presented as followed in Table 1. As shown in Table 2, the mean values of the four variables from the lowest to the highest in succession are grit (34.85), organizational commitment (42.17), employability (43.78), and job involvement (44.03).

Table 1

Descriptive Statistics

\begin{tabular}{lccccc}
\hline & & Grit & Employability & Job Involvement & Organizational Commitment \\
\hline N & Valid & 130 & 130 & 130 & 130 \\
Mean & Missing & 0 & 0 & 0 & 0 \\
Median & & 34.85 & 43.78 & 44.03 & 42.17 \\
Mode & 35.00 & 44.00 & 44.50 & 41.00 \\
Std. Deviation & 32 & 40 & 40 & 40 \\
Variance & 3.566 & 4.156 & 4.319 & 4.701 \\
Range & 12.715 & 17.275 & 18.650 & 22.095 \\
Minimum & 16 & 28 & 30 & 30 \\
Maximum & 24 & 22 & 20 & 20 \\
Sum & 40 & 50 & 50 & 50 \\
\hline
\end{tabular}

Table 2 shows all indicators on each variable have significant relationships with the indicators of the other variables at level $\mathrm{p}<.05$. This condition indicates that all the indicators of all variables have a mutual relationship with each other.

Table 2

Correlation matrix of indicators

\begin{tabular}{|c|c|c|c|c|c|c|c|c|c|c|c|c|c|}
\hline & 1 & 2 & 3 & 4 & 5 & 6 & 7 & 8 & 9 & 10 & 11 & 12 & 13 \\
\hline \multicolumn{14}{|l|}{ Grit } \\
\hline 1. CI & 1.00 & & & & & & & & & & & & \\
\hline 2. $\mathrm{PE}$ & $.79 *$ & 1.00 & & & & & & & & & & & \\
\hline \multicolumn{14}{|l|}{ Employability } \\
\hline 3. SJSC & $.49^{*}$ & $.58 *$ & 1.00 & & & & & & & & & & \\
\hline 4. Pro & $.56^{*}$ & $.52 *$ & $.66^{*}$ & 1.00 & & & & & & & & & \\
\hline 5. Ada & $.60^{*}$ & $.58 *$ & $.53 *$ & $.66^{*}$ & 1.00 & & & & & & & & \\
\hline 6. WF & $.65^{*}$ & $.61 *$ & $.51 *$ & $.66^{*}$ & $.70 *$ & 1.00 & & & & & & & \\
\hline 7. BBOP & $.43^{*}$ & $.39 *$ & $.18^{*}$ & $.26^{*}$ & $.26^{*}$ & $.29 *$ & 1.00 & & & & & & \\
\hline \multicolumn{14}{|c|}{ Job Involvement } \\
\hline 8. APW & $.41^{*}$ & $.38 *$ & $.39 *$ & $.33^{*}$ & $.39 *$ & $.38^{*}$ & $.33^{*}$ & 1.00 & & & & & \\
\hline 9. SWMT & $.53^{*}$ & $.54^{*}$ & $.53 *$ & $.55^{*}$ & $.56^{*}$ & $.52 *$ & $.36^{*}$ & $.43^{*}$ & 1.00 & & & & \\
\hline 10. CWIS & $.55^{*}$ & $.56^{*}$ & $.46^{*}$ & $.51 *$ & $.62 *$ & $.58^{*}$ & $.43 *$ & $.49 *$ & $.72 *$ & 1.00 & & & \\
\hline \multicolumn{14}{|c|}{ Organizational Commitment } \\
\hline 11. Aff & $.43^{*}$ & $.45^{*}$ & $.27 *$ & $.43 *$ & $.47 *$ & $.47^{*}$ & $.40 *$ & $.28^{*}$ & $.41^{*}$ & $.55^{*}$ & 1.00 & & \\
\hline 12. Nor & $.61^{*}$ & $.63 *$ & $.37 *$ & $.43^{*}$ & $.54 *$ & $.54^{*}$ & $.56^{*}$ & $.49 *$ & $.61^{*}$ & $.65^{*}$ & $.50 *$ & 1.00 & \\
\hline 13. Con & $.53 *$ & $.50 *$ & $.32 *$ & $.40 *$ & $.48^{*}$ & $.57 *$ & $.45^{*}$ & $.46^{*}$ & $.49 *$ & $.65^{*}$ & $.70 *$ & $.54 *$ & 1.00 \\
\hline
\end{tabular}

$* \mathrm{p}<.05$

The results of hypothesis testing with path analysis of the effects of grit and employability on job involvement and organizational commitment are summarized in Table 3 and visualized in Fig. 2 and Fig. 3. The hypothesis testing results in Table 3 show that all hypotheses were supported (t-value $>$ t-table at $\alpha=.05$ and .01 ). Therefore the result of this study indicate that grit, employability, and job involvement had significant direct effects on organizational commitment, then grit and employability had significant direct effects on job involvement. Besides, the results of this study have also shown grit and employability had significant indirect effects on an organizational commitment by mediating job involvement, each with path coefficient $=.07 *$ and $.024 * *$ and $\mathrm{t}$-value $=1.78$ and 3.88. In Fig. 2 and Fig. 3, the test results of the model with the goodness of fit statistics show the significant with Chi-Square $=0.000, \mathrm{df}=0$, p-value $=1.00000>.05$ and $\mathrm{RMSEA}=.000<.08$, so that the model tested is fit. That means the theoretical model being tested is supported by empirical data. 
Table 3

Summary of path coefficients and t values

\begin{tabular}{lccc}
\hline Hypothesis & Path Coefficients & T Value & Hypothesis Testing \\
\hline $\mathrm{H}_{1}$ : Grit $\left(\mathrm{X}_{1}\right)$ on organizational commitment $\left(\mathrm{Y}_{2}\right)$ & $.17^{*}$ & 2.02 & Supported \\
$\mathrm{H}_{2}$ : Employability $\left(\mathrm{X}_{2}\right)$ on organizational commitment $\left(\mathrm{Y}_{2}\right)$ & $.28^{* *}$ & 2.83 & Supported \\
$\mathrm{H}_{3}$ : Job involvement $\left(\mathrm{Y}_{1}\right)$ on organizational commitment $\left(\mathrm{Y}_{2}\right)$ & $.40^{* *}$ & 4.75 & Supported \\
$\mathrm{H}_{4}$ : Grit $\left(\mathrm{X}_{1}\right)$ on job involvement $\left(\mathrm{Y}_{1}\right)$ & $.17^{*}$ & 1.92 & Supported \\
$\mathrm{H}_{5}$ : Employability $\left(\mathrm{X}_{2}\right)$ on job involvement $\left(\mathrm{Y}_{1}\right)$ & $.60^{* *}$ & 6.73 & Supported \\
\hline
\end{tabular}

$* \mathrm{p}<.05$

$* * \mathrm{p}<.01$

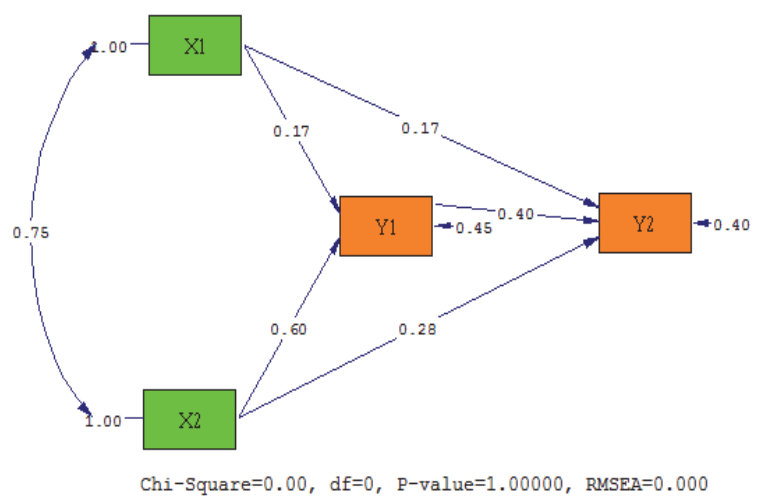

Fig. 2. Path Coefficients

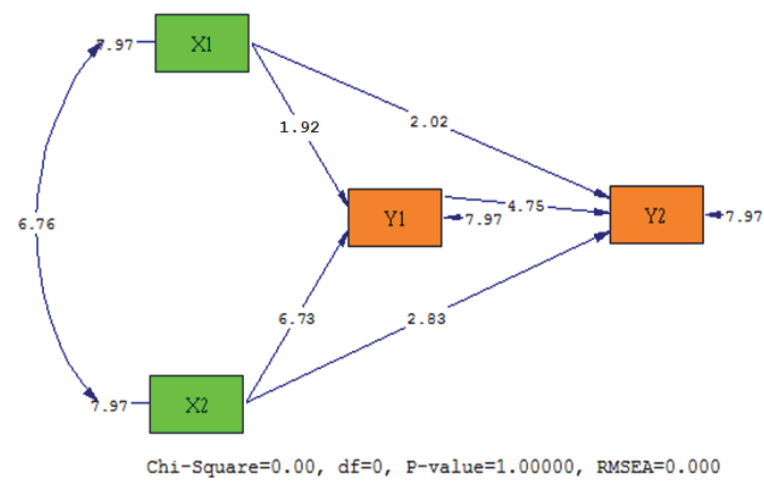

Fig. 3. $T$ Values

\section{Discussion}

The results have revealed that grit and employability had significant effects on organizational commitment, either directly or indirectly by mediating job involvement. The results of the correlation test between indicators for all variables as a whole have shown significant relationships. Finally, the result of a fit model test also shows that the theoretical model was in accordance (fit) with empirical data. This finding confirms that grit, employability, and job involvement are adequate determinant for organizational commitment. Moreover, job involvement plays a significant role as a mediator of the effect of grit and employability on organizational commitment. These findings were consistent with other results used as a reference to build this research hypothesis.

In reality, lecturers of private higher education who has the consistency of interests reflects an individual's tendency to maintain commitment and maintain focus on achieving goals/tasks over a long period time; and persistence of effort, reflects an individual's tendency to pursue long-term goals with sustained efforts despite obstacles and setbacks tend to have an affective commitment (emotional attachment to, identification with, and involvement in the organization), continuance commitment (based on the costs that the employee associates with leaving the organization), and normative commitment (feelings of obligation to stay with the organization because they should; it is the right thing to do). For example, lecturers with high persistence of effort tend to involvement and obligation to the organization. This is consistent with the results of correlational analysis between indicators which confirm that all grit indicators have a significant relationship with all organizational commitment indicators. These findings are consistent with the research results of Seo, Kim, and Park (2014) who show that grit influences organizational commitment.

Besides, lecturers of private higher education that have adequate employability, which is characterized by specific work skills and competencies that are more general, proactive, adaptability, work feelings, a balance between organizational and personal interests tend to motivate lecturers to show affective, continuance, and normative commitment. For example, lecturers who proactive tend to involvement in the organization as part of affective commitment. This is consistent with the results of correlational analysis between indicators which show that all employability indicators have a significant relationship with all organizational commitment indicators. The research results of Benson (2006), De Cuyper and De Witte (2011), Yousaf and Sanders (2012), and Aryani and Widodo (2020) also prove that employability affects organizational commitment. 
The lecturers of private higher education can manage and develop his job involvement in good condition who manifested in active participation in work, showing work is the main thing and considers work as important to his self-esteem also well have great potential to encourage the emergence of affective, normative, and continuance commitments. As an illustration, lecturers who active participation in work tend to involvement in the organization as part of affective commitment. The lecturers who showing work is the main thing also tend to the obligation to stay with the organization as part of normative commitment. This is consistent with the results of correlational analysis between indicators that prove all job involvement indicators have a significant relationship with all organizational commitment indicators. Studies conducted by Zopiatis, Constanti, and Theocharous (2014), Singh and Gupta (2015), and Abdallah et al. (2017) also report that job involvement affects organizational commitment.

Moreover, the lecturers of private higher education can manage their consistency of interests and persistence of effort in good condition can also have implications for increasing active participation in work, showing work is the main thing and considers work as important to his self-esteem of lecturers. For example, lecturers whose consistent interests tend to consider work as important to his self-esteem. As shown by the results of correlational analysis between indicators, all indicators of grit and job involvement are significant. The results of research by Jeong et al. (2019) and Arifin et al. (2019) also indicate that grit affects job involvement.

Finally, seriousness and success of lecturers of private higher education in managing and building their employability especially specific work skills and competencies that are more general, proactive, adaptability, work feelings, a balance between organizational and personal interests also can stimulate an increase active participation in work, showing work is the main thing and considers work as important to his self-esteem of lecturers. As an illustration, lecturers who proactive ten to active participation in work. This is in line with the results of correlational analysis between indicators of the employability and job involvement variables, which are all significant. The investigation of Andrews and Russlell (2012) indicate that employability influences job involvement.

The results of this study confirm the results of several such studies and find a new empirical model based on the data of private higher education lecturers in Indonesia, which can be adopted as a conceptual or theoretical model of future research that can be utilized by researchers concern on contemporary organizational commitment issues. For organizational and management practitioners, this new model can be used as a strategic alternative to develop and building organizational commitment lecturers or employees. As a focus in this context is optimal of grit, employability, and job involvement through organizational engineering that allows grit, employability, and job involvement lecturers can grow well continuously so that it can trigger the emergence of a new spirit that initiates the growth of organizational commitment that is stronger and adequate among lecturers or employees.

\section{Conclusion and Recommendation}

This research has reported that grit, employability, and job involvement had significant direct effects on organizational commitment, grit and employability had significant direct effects on job involvement, and then grit and employability had significant indirect effects on the organizational commitment by mediating job involvement. Therefore, a fit research model was found about the effect of grit and employability on the organizational commitment by mediating job involvement with the research setting of the lecturers of private higher education in Indonesia. This model can be used as a reference by researchers and practitioners in developing models of organizational commitment that are following their actual conditions and also be further developed and expanded into research, studies, and projects to develop organizational commitment which is more comprehensive, holistic, and complex by adding variables and other relevant indicators.

\section{Acknowledgments}

We are very grateful to the lecturers in Indonesia who volunteered to spend their time and full dedication to responding to every statement item in the questionnaire completely and perfectly so that it could be used as research material in this article. May this willingness and dedication be a contribution to the development of science that can seeding to civilization.

\section{References}

Abdallah, A.B., Obeidat, B.Y., Aqqad, N.O., Al Janini, M.N.K., \& Dahiyat, S.E. (2017). An integrated model of job involvement, job satisfaction and organizational commitment: a structural analysis in Jordan's banking sector. Scientific Research Publishing In Communications and Network, 9, 28-53.

Andrews, G., \& Russell, M. (2012). Employability skills development: strategy, evaluation, and impact. Higher Education, Skills and Work-Based Learning, 2(1), 33-44.

Arifin, M., Herri, Amali, H., Elfindri, \& Puteri, H.E. (2019). Personality, grit and organizational citizenship behavior at vocational higher education: the mediating role of job involvement. Journal of Social Studies Education Research, 10(2), 168-187. 
Aryani, R., \& Widodo, W. (2020). Exploring the effect of employability and job characteristics on contextual performance: Mediating by organizational commitmentt. Management Science Letters, 10(9), 2071-2076.

Beardwell, J., \& Thompson, A. (2014). Human resource management: A contemporary approach. Eighth edition. United Kingdom: Pearson Education Limited.

Benson, G. S. (2006). Employee development, commitment and intention to turnover: a test of 'employability'policies in action. Human Resource Management Journal, 16(2), 173-192.

Berntson, E., \& Marklund, S. (2007). The relationship between perceived employability and subsequent health. Work \& Stress, $21,279-292$.

De Cuyper, N., \& De Witte, H. (2011). The management paradox: Self-rated employability and organizational commitment and performance. Personnel Review, 40(2), 152-172.

Duckworth, A.L., Peterson, C., Matthews, M.D., \& Kelly, D.R. (2007). Grit: Perseverance and passion for long-term goals. Journal of Personality and Social Psychology, 92(6), 1087-1101.

Duckworth, A. L. \& P. D. Quinn. (2009). Development and validation of the short grit scale (Grit-S). Journal of Personality Assessment, 91(2), 166-174.

Duckworth, A. L. (2016). Grit: The power of passion and perseveranve. New York: Sribner.

Ekmekçi, A.K. (2011). A study on involvement and commitment of employees in Turkey. Journal of Public Administration and Policy Research, 3(3), 68-73.

Emami, M. (2012). The relationship between job involvement, job satisfaction and organizational commitment among lowerlevel employees. Asian Journal of Social and Economic Sciences (AJSES), 1(1), 23-33.

Esfahani, M., Emami, M., \& Tajnesaei, H. (2013). The investigation of the relation between job involvement and organizational commitment. Management Science Letters, 3(2), 511-518.

Fugate, M., Kinicki, A.J. and Ashforth, B.E. (2004). Employability: a psycho-social construct, its dimensions, and applications. Journal of Vocational Behavior, 65, 14-38.

Griesel, H., \& Parker, B. (2009). Graduate attributes: A baseline study on South African graduates from the perspective of employers. Pretoria: Higher Education South Africa and South African Qualifications Authority.

Hair, J.F., Balck, W. C., Babin, B. J., \& Anderson, R.E. (2010). Multivariate data analysis. 7th edition. Boston: Pearson.

Ho, C.C., Oldenburg, B., Day, G., \& Sun, J. (2012). Work values, job involvement, and organizational commitment in Taiwanese nurses. International Journal of Psychology and Behavioral Sciences, 2(3), 64-70.

Hochanadel, A., \& Finamore, D. (2015). Fixed and growth mindset in educational and how grit helps students persists in the face of adversity. Journal of International Education Research, 11(1), 47-50.

Jeong, J.Y., Seo, Y.S., Choi, J.H., Kim, S.H., Lee, M.S., Hong, S.H., Choi, J.S., \& Park, D.E. (2019). The influence of grit on turnover intention of university hospital nurses: The mediating effect of job involvement. Journal Korean Society of Nursing Science, 49(2), 181-190.

Kuruüzüm, A., Cetin, E. I., \& Irmak, S. (2009). Path analysis of organizational commitment, job involvement and job satisfaction in Turkish hospitality industry. Tourism Review, 64(1), 4-16.

Ling, L., Qing, T., \& Shen, P. (2014). Can training promote employee organizational commitment? The effect of employability and expectation value. Nankai Business Review International, 5, 2, 162-186.

Macey, W. H., \& Schneider, B. (2008). The meaning of employee engagement. Industrial and Organizational Psychology, 1.

Meyer, J. P., \& Allen, N.J. (1991). A three-component conceptualization of organizational commitment. Human Resource Management Review, 1, 61-89.

Newstrom, J. W. (2015). Organization behavior: Human behavior at work, $12^{\text {th }}$ edition. Boston: McGraw Hill.

Noe, R.A., Hollenbeck, J.R., Gerhart, B., \& Wright, P.M. (2015). Human resource management: Gaining a competitive advantage, $9^{\text {th }}$ global edition. New York: McGraw-Hill Education.

Robbins, S. P., \& Judge, T. A. (2013). Organizational behavior, sixteenth edition. Essex: Pearson Education Limited.

Rothwell, A., Herbert, I., \& Rothwell, F. (2008). Self perceived employability: Construction and initial validation of a scale for university students. Journal of Vocational Behavior, 73, 1-12.

Seo, K.S, Kim, M., \& Park, J. (2014). Effect of resilience and job satisfaction on organizational commitment in KoreanAmerican registered nurses. Journal of Korean Academy of Nursing Administration, 20(1), 48-58.

Singh, A., \& Gupta, B. (2015). Job involvement, organizational commitment, professional commitment, and team commitment. Benchmarking: An International Journal, 22(6) 1192-1211.

Van der Heijde, C.M., \& Van der Heijden, B.I.J.M. (2006). A competence-based and multidimensional operationalization and measurement of employability. Human Resource Management, 45(3), 449-476.

Von Culin, K., Tsukayama, E., \& Duckworth, A. L. (2014). Unpacking grit: Motivational correlates of perseverance and passion for long-term goals. The Journal of Positive Psychology, 9(4), 306-312.

Yousaf, A., \& Sanders, K. (2012). The role of job satisfaction and self-efficacy as mediating mechanisms in the employability and affective organizational commitment relationship: a case from a Pakistani university. Thunderbird International Business Review COMSATS Institute of Information Technology, 54(6), 907-919.

Zopiatis, A., Constanti, P., \& Theocharous, A.L. (2014). Job involvement, commitment, satisfaction and turnover: evidence from hotel employees in cyprus. Tourism Management, 41, 129-140. 
(C) 2020 by the authors; licensee Growing Science, Canada. This is an open access article distributed under the terms and conditions of the Creative Commons Attribution (CC-BY) license (http://creativecommons.org/licenses/by/4.0/). 